\title{
Protective Effects of Wogonin against Alzheimer's Disease by Inhibition of Amyloidogenic Pathway
}

\author{
Ding-Siang Huang, Yu-Chen Yu, Chung-Hsin Wu, and Jung-Yaw Lin \\ Department of Life Science, National Taiwan Normal University, Taipei, Taiwan \\ Correspondence should be addressed to Chung-Hsin Wu; megawu@ntnu.edu.tw and Jung-Yaw Lin; linjy@ntu.edu.tw
}

Received 9 January 2017; Revised 15 March 2017; Accepted 12 April 2017; Published 7 June 2017

Academic Editor: Ling Yang

Copyright (C) 2017 Ding-Siang Huang et al. This is an open access article distributed under the Creative Commons Attribution License, which permits unrestricted use, distribution, and reproduction in any medium, provided the original work is properly cited.

\begin{abstract}
One of the pathogenic systems of Alzheimer's disease (AD) is the formation of $\beta$-amyloid plaques in the brains of patients, and amyloidogenic activity becomes one of the therapeutic targets. Here, we report wogonin, one of the major active constituting components in Scutellaria baicalensis, which has the neuroprotective effects on amyloid- $\beta$ peptides- (A $\beta$-) induced toxicity. Oral wogonin treatment improved the performance of triple transgenic AD mice (h-APPswe, h-Tau P301L, and h-PS1 M146V) on the Morris water maze, Y-maze, and novel object recognition. Furthermore, wogonin activated the neurite outgrowth of AD cells by increasing neurite length and complexity of Tet-On A $\beta_{42}$-GFP SH-SY5Y neuroblastoma cells (AD cells) and attenuated amyloidogenic pathway by decreasing the levels of $\beta$-secretase, APP $\beta$-C-terminal fragment, $\mathrm{A} \beta$-aggregation, and phosphorylated Tau. Wogonin also increased mitochondrial membrane potential $(\Delta \psi \mathrm{m})$ and protected against apoptosis by reducing the expression of Bax and cleaved PARP. Collectively, these results conclude that wogonin may be a promising multifunctional drug candidate for $\mathrm{AD}$.
\end{abstract}

\section{Introduction}

Alzheimer's disease $(\mathrm{AD})$ is a progressive neurodegenerative disease that is characterized by the aggregation of extracellular amyloid $\beta(\mathrm{A} \beta)$ peptides and intracellular neurofibrillary tangles of hyperphosphorylated Tau protein and is resulting in cognitive deficits and memory loss $[1,2]$. A $\beta$ plaque is composed of $\mathrm{A} \beta_{42}$ and $\mathrm{A} \beta_{40}$ peptides that are the major forms in the brain of $\mathrm{AD}$ patient. In the amyloidogenic pathway, $\mathrm{A} \beta$ generation is mediated by amyloid precursor protein processing that is subsequently proteolysis by $\beta$-secretase and $\gamma$-secretase. The $\beta$-secretase, as $\beta$-site amyloid precursor protein cleaving enzyme 1 (BACE1), is a rate-limiting enzyme that modulates $A \beta$ production $[3,4]$, and overproduction of $\mathrm{A} \beta$ peptides is known to self-assemble into dimers and high molecular weight oligomers to form fibrils [5-7] that induce neurotoxicity and contribute to $\mathrm{AD}$ symptoms [8-10]. Accordingly, inhibition of BACE1 activity is a potent strategy for treating AD.
Mitochondria are targets of $\mathrm{A} \beta$ that accumulates in the membrane of mitochondria, and mitochondrial function is disrupted in an early phase of $\mathrm{AD}$ [11-15], suggesting that $\mathrm{A} \beta$ aggregation is involved in mitochondria-mediated apoptosis $[16,17]$. It has been reported that $A \beta$ leads to cytochrome $C$ release through mitochondrial membrane permeabilization $[18,19]$ that induces mitochondrial-mediated apoptosis.

Wogonin is an active compound of Scutellaria baicalensis Georgi, and the effects of wogonin on anti-inflammatory and antioxidation have been studied in various cell types [20-22]. In the present study, the effects of wogonin on BACE1 activity and $A \beta$ oligomerization were investigated. Our findings demonstrated that wogonin inhibited amyloid precursor protein (APP) processing in the $\beta$-secretase pathway, the phosphorylation of Tau protein, and $\mathrm{A} \beta$ aggregation in human neuroblastoma cells and exhibited protective effects on learning and memory impairments in the Morris water maze test, Y-maze, and the novel object recognition test of 3xTg-AD mice. 


\section{Materials and Methods}

2.1. Materials. $\mathrm{A} \beta_{42}$ peptide was obtained from Anaspec (Fremont, CA, USA). 1,1,1,3,3,3-Hexafluoro-2-propanol (HFIP) was purchased from Matrix Scientific (Columbia, SC, USA). Thioflavin T (ThT) was obtained from Abcam (Cambridge, MA, USA). Tris (2,2' -bipyridine)dichlororuthenium(II) hexahydrate $\left(\mathrm{Ru}(\mathrm{Bpy})_{3}\right)$ was purchased from Santa Cruz Biotechnology, Inc. (Dallas, TX, USA). 3-(4,5-Dimethylthiazol2-yl)-2,5-diphenyltetrazolium bromide (MTT), ammonium persulfate (APS), and retinoic acid (RA) were purchased from Sigma-Aldrich Co. LLC (St. Louis, MO, USA). Dulbecco's Modified Eagle's Medium that contained the F-12 nutrient mixture (DMEM/F12), penicillin/streptomycin, hygromycin B, blasticidin S, and The MitoProbe ${ }^{\mathrm{TM}} \mathrm{JC}-1$ Assay Kit were obtained from Invitrogen (Grand Island, NY, USA).

Oligomer A11 antibody was obtained from Invitrogen (Grand Island, NY, USA). The antibodies against Bax and cleaved poly (ADP-ribose) polymerase (PARP) were purchased from Cell Signaling Technology, Inc. (Danvers, MA, USA), and those against BACE1, phospho-Tau (Ser396), total Tau (A-10), and actin were obtained from Santa Cruz Biotechnology, Inc. (Dallas, TX, USA). The antibody against $\beta$ amyloid $_{1-16}(6 \mathrm{E} 10)$ was obtained from Covance Inc. (Princeton, NJ, USA).

2.2. Cell Culture. Tet-On A $\beta_{42}$-GFP SH-SY5Y neuroblastoma cells were cultured with DMEM/F12 containing $10 \%$ fetal bovine serum, $1 \%$ penicillin/streptomycin, $0.1 \%$ hygromycin $\mathrm{B}$, and $0.05 \%$ blasticidin $\mathrm{S}$ at $37^{\circ} \mathrm{C}$ in a humid $5 \%$ $\mathrm{CO}_{2}$ environment.

2.3. Cell Viability. Cell viability was evaluated by MTT assay by using Tet-On A $\beta_{42}$-GFP SH-SY5Y neuroblastoma cells. Cells were plated in a final volume of $100 \mu \mathrm{L}$ of medium with $10 \mu \mathrm{M}$ retinoic acid (RA) in 96-well plates $\left(1 \times 10^{4}\right.$ cells/well). After 24-hour incubation, the cells were treated with various concentrations of wogonin for five days. After the treatment, cells were incubated with $0.5 \mathrm{mg} / \mathrm{ml}$ MTT for three hours. The formazan crystals were dissolved by acid-SDS solution $(10 \%$ sodium dodecyl sulfate and $0.01 \mathrm{~N} \mathrm{HCl})$, and the absorbance was recorded at a wavelength of $570 \mathrm{~nm}$ with an ELISA reader (uQuant, BioTek Instruments, Inc., Winooski, VT, USA).

2.4. Acetylcholinesterase (AChE) Activity Assay. Tet-On $\mathrm{A} \beta_{42}$-GFP SH-SY5Y neuroblastoma cells were plated in the 6 -well plate at density of $1 \times 10^{5}$ cells/well with $10 \mu \mathrm{M}$ RA and pretreated with wogonin $(10$ and $25 \mu \mathrm{M})$ for 24 hours. Cells were then induced to express $\mathrm{A} \beta_{42}$-GFP for five days by treating with $10 \mu \mathrm{g} / \mathrm{mL}$ doxycycline. Briefly, cells were homogenized in ice-cold phosphate-buffered saline (PBS, $\mathrm{pH} 7.4$ ) and then centrifuged at $13,000 \mathrm{rpm}$ for $20 \mathrm{~min}$ at $4^{\circ} \mathrm{C}$. The supernatant was performed by Acetylcholinesterase Assay Kit (KA1607, Abnova Corp., Taiwan) where reactions were monitored by measuring the absorbance at $412 \mathrm{~nm}$.

2.5. Thioflavin $T$ Assay. The freshly prepared $\mathrm{A} \beta_{42}$ peptides $(20 \mu \mathrm{M})$ with/without wogonin $(10 \mu \mathrm{M})$ were added in a $100 \mu \mathrm{L}$ sample containing $50 \mathrm{mM}$ glycine and $40 \mu \mathrm{M}$ Thioflavin T. The samples were loaded in a 96-well plate and florescent intensity of each sample was measured by excitation of $440 \mathrm{~nm}$ and emission of $490 \mathrm{~mm}$ every $30 \mathrm{~min}$ at $37^{\circ} \mathrm{C}$ for 16 hours.

2.6. Photo-Induced Cross-Linking of Unmodified Proteins (PICUP). The PICUP was performed as described with a small modification [23]. Briefly, HFIP-treated $\mathrm{A} \beta_{42}$ peptide film was dissolved at a concentration of $30 \mu \mathrm{M}$ in $10 \%$ (vol/vol) $60 \mathrm{mM} \mathrm{NaOH}$ and 90\% (vol/vol) $10 \mathrm{mM}$ sodium phosphate buffer ( $\mathrm{pH} 7.4)$. The peptide solution was centrifuged at $16,000 \times \mathrm{g}$ for $10 \mathrm{~min}$ after $5 \mathrm{~min}$ sonication by water bath sonicator. The supernatant was used immediately. $17 \mu \mathrm{L}$ peptide solution was mixed with $1 \mu \mathrm{L} \mathrm{Ru}(\mathrm{Bpy})_{3}(1 \mathrm{mM})$ and $1 \mu \mathrm{L}$ APS $(20 \mathrm{mM})$, and the mixture was irradiated for $1 \mathrm{sec}$ with visible light in a closed chamber. The reaction was quenched immediately by adding $1 \mu \mathrm{L}$ DTT and sample buffer and then kept on ice before analysis by SDS-PAGE.

2.7. Dot-Blot Assay. A $\beta_{42}$ was dissolved at a concentration of $2 \mathrm{mM}$ in $100 \mathrm{mM} \mathrm{NaOH}$ and followed by water bath sonication for $30 \mathrm{sec}$, and the $\mathrm{A} \beta_{42}$ stock solution was then diluted to $45 \mu \mathrm{M}$ by adding PBS ( $\mathrm{pH} 7.4$ ) containing $0.02 \%$ sodium azide. The $\mathrm{A} \beta_{42}$ working solution was incubated with/without $10 \mu \mathrm{M}$ wogonin at room temperature for different periods ( 0,1 , and 3 days), and the sample was spotted onto nitrocellulose membrane and filtered on a Bio-Dot apparatus (Bio-Rad). The membrane was blocked by $5 \%$ nonfat milk in TBST for 1 hour at room temperature, and then membrane was incubated with A11 polyclonal antibody $(1: 1000)$ or $6 \mathrm{E} 10$ monoclonal antibody $(1: 1000)$ for overnight at $4^{\circ} \mathrm{C}$, followed by incubation with secondary anti-rabbit or anti-mouse antibody conjugated with horseradish peroxidase (1:5000) followed by ECL detection.

2.8. Western Blot Analysis. After treatments, Tet-On $\mathrm{A} \beta_{42^{-}}$ GFP SH-SY5Y neuroblastoma cells and cerebral tissue of mice were lysed with radioimmunoprecipitation assay buffer on ice for $10 \mathrm{~min}$, which was followed by sonication and centrifugation at $13,000 \mathrm{rpm}$ at $4^{\circ} \mathrm{C}$ for $20 \mathrm{~min}$. Equal amounts of the protein samples $(40 \mu \mathrm{g})$ and the standard protein molecular weight markers were separated by sodium dodecyl sulfate-polyacrylamide gel electrophoresis and blocked with dried 5\% skim milk. An immunoblot analysis was performed followed by enhanced chemiluminescence detection.

2.9. Mitochondrial Membrane Potential Analysis. Tet-On $\mathrm{A} \beta_{42}$-GFP SH-SY5Y cells were plated in 6-well plates at a density of $1 \times 10^{5}$ cells/well with $10 \mu \mathrm{M}$ RA. After 24 hours, cells were pretreated with $10 \mu \mathrm{M}$ wogonin for 24 hours and then treated with $10 \mu \mathrm{g} / \mathrm{ml}$ Dox to express $\mathrm{A} \beta_{42}$-GFP for five days. Cells were harvested and stained by using JC-1 dye for one hour; then the cells were measured with a flow cytometry (FACSCalibur, Becton Dickinson, San Jose, CA, USA) and analyzed with CellQuest software. A total number of 10,000 cells were recorded for each group. 


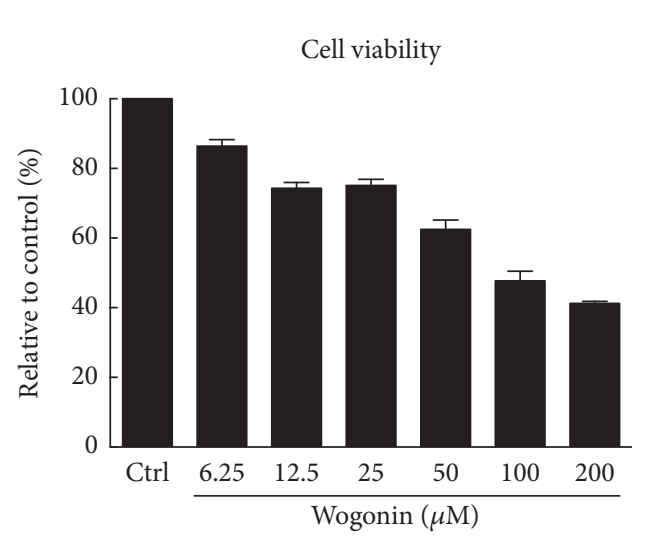

(a)

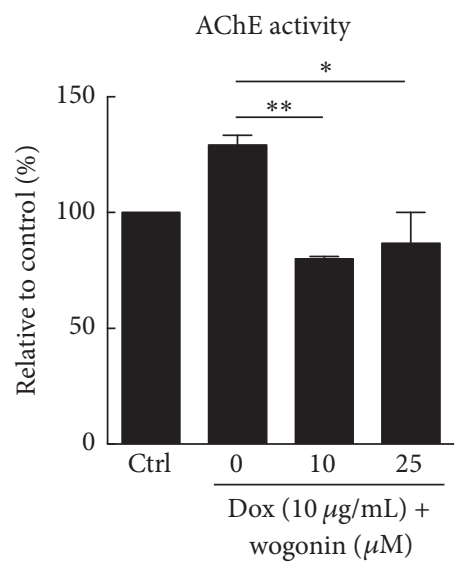

(b)

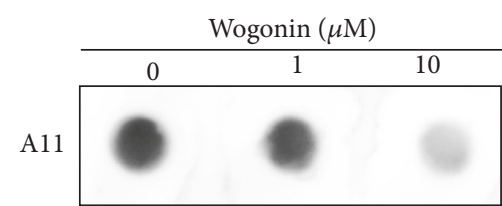

$6 \mathrm{E} 10$

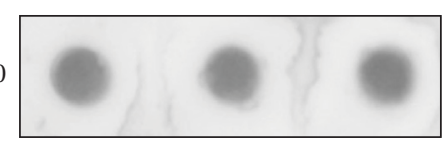

(c)

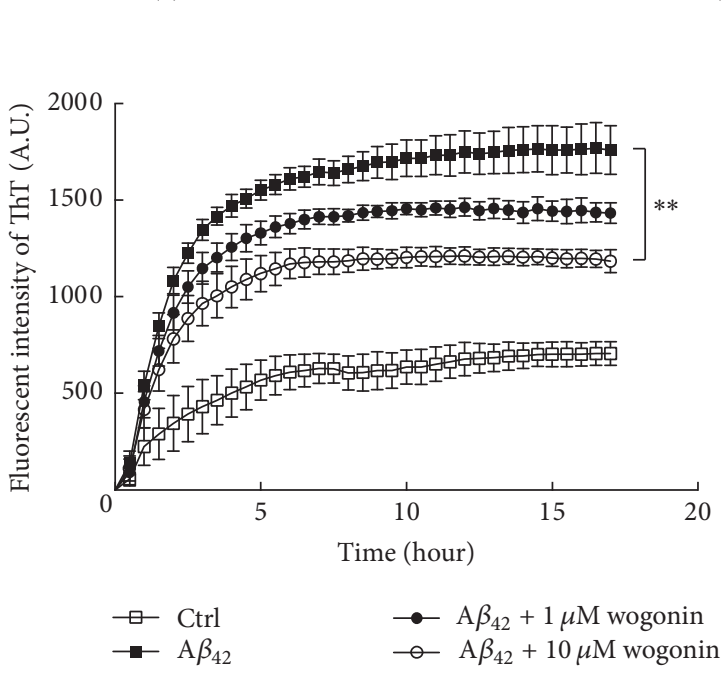

(d)

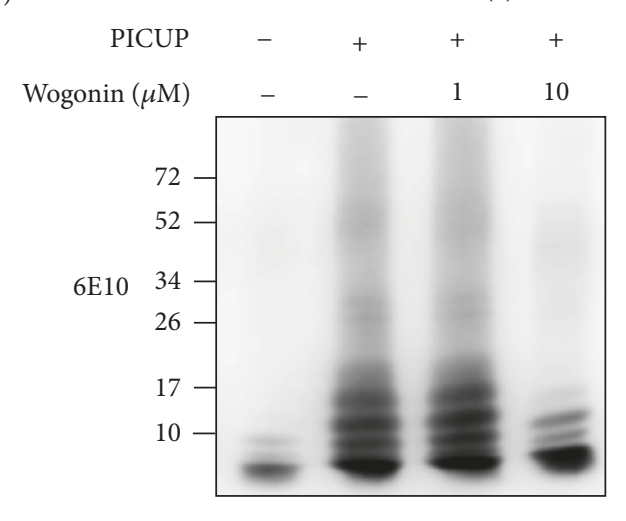

(e)

FIGURE 1: Effects of wogonin on AChE activity, A $\beta_{42}$ oligomerization, and fibrillization. (a) Tet-On A $\beta 42-G F P$ SH-SY5Y cells were treated with various concentrations of wogonin $(6.25-200 \mu \mathrm{M})$, and cell viability was measured by MTT assay. (b) Tet-On A $\beta_{42}$-GFP SH-SY5Y cells were induced with $10 \mu \mathrm{g} / \mathrm{mL}$ doxycycline in the absence or presence of wogonin $(10$ and $25 \mu \mathrm{M})$ for five days, and AChE activity was then measured by Acetylcholinesterase Assay Kit. (c) $\mathrm{A} \beta_{42}(45 \mu \mathrm{M})$ was incubated in the absence or presence of wogonin $(1$ and $10 \mu \mathrm{M})$ at room temperature for 3 days and then performed by dot-blot assay. $\mathrm{A} \beta_{42}$ oligomers were detected by using oligomer All polyclonal antibody, and total $\mathrm{A} \beta_{42}$ were performed by using $6 \mathrm{E} 10$ antibody. (d) HFIP-treated $\mathrm{A} \beta_{42}(20 \mu \mathrm{M})$ was incubated in the absence or presence of wogonin (1 and $10 \mu \mathrm{M}$ ) assayed by Thioflavin T (ThT), and the fluorescent intensity (excitation/emission $=440 \mathrm{~nm} / 490 \mathrm{~nm}$ ) was recorded every 30 min for 16 hours at $37^{\circ} \mathrm{C}$. (e) $\mathrm{A} \beta_{42}(25 \mu \mathrm{M})$ in the absence or presence of wogonin $(1 \mu \mathrm{M}$ or $10 \mu \mathrm{M})$ was subjected to photo-induced cross-linking unfolded proteins (PICUP) and SDS-PAGE analysis to examine $\mathrm{A} \beta$ oligomerization. ${ }^{*} p<0.05,{ }^{* *} p<0.01$.

2.10. Quantitative Analysis of Neurite Outgrowth. Neurite outgrowth of Tet-On A $\beta_{42}$-GFP SH-SY5Y cells was measured with a Sholl analysis [24]. The cells were plated in 6-well plates at a density of $5 \times 10^{4}$ cells/well with $10 \mu \mathrm{M}$ RA, pretreated with $10 \mu \mathrm{M}$ wogonin for 24 hours, and then induced with $10 \mu \mathrm{g} / \mathrm{mL}$ Dox for five days. The cells were washed with PBS and fixed with $4 \%$ paraformaldehyde for $15 \mathrm{~min}$, which were followed by staining with $0.25 \%(\mathrm{w} / \mathrm{v})$ crystal violet in $2 \%$ ethanol/water for $30 \mathrm{~min}$ at room temperature. The samples were observed with a microscope, and neurite outgrowth was analyzed as the length of the neurite, while neurite complexity was determined by the number of intersections of the neurites and concentric circles.
2.11. Immunohistochemistry (IHC). 3xTG-AD mice were cardiac perfused with phosphate-buffered saline (PBS) and then fixed with $4 \%$ formaldehyde (EM grade) at the age of 24 weeks. The brain specimens were embedded in paraffin. Sagittal sections $(5 \mu \mathrm{m})$ of cortex and hippocampus were then stained with 6E10 antibody (Santa Cruz, California, USA) for 1 hour at room temperature, followed by incubation with biotinylated secondary antibody (Novolink ${ }^{\mathrm{TM}}$ Polymer Detection System 1; Leica, Wetzlar, Germany) for $30 \mathrm{~min}$ at room temperature. The sections were then incubated with avidinbiotin HRP complex (Novolink Polymer Detection System 1) for $30 \mathrm{~min}$ at room temperature. Finally, visualization was performed with DAB Chromogen (Novolink Polymer 


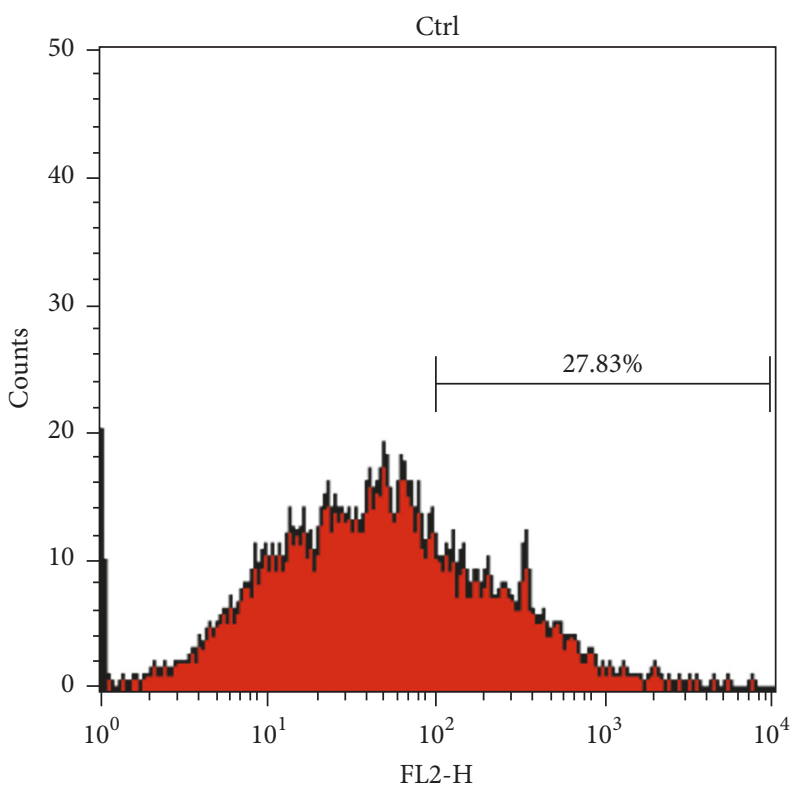

(a)

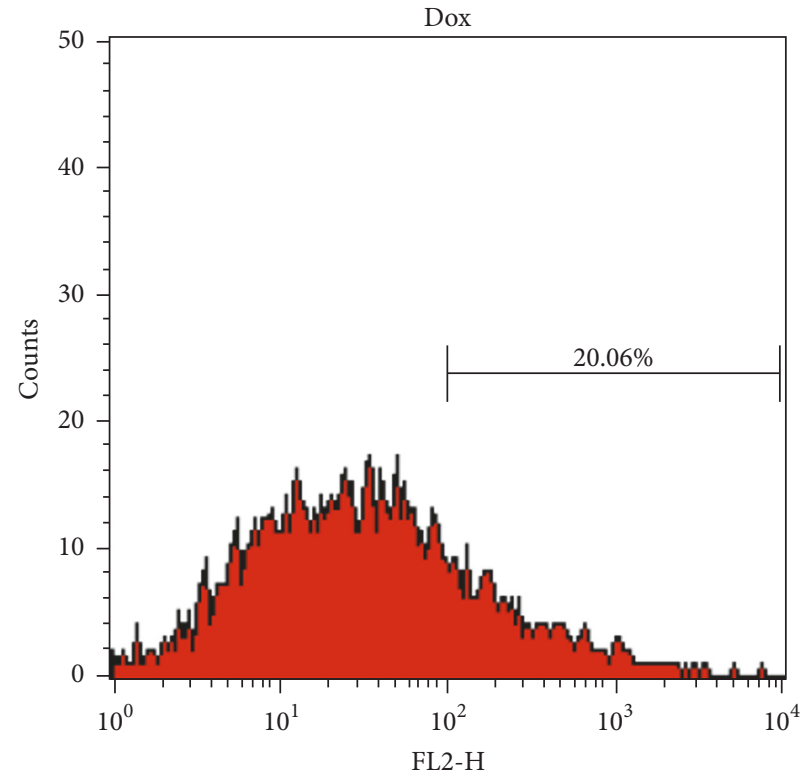

(b)

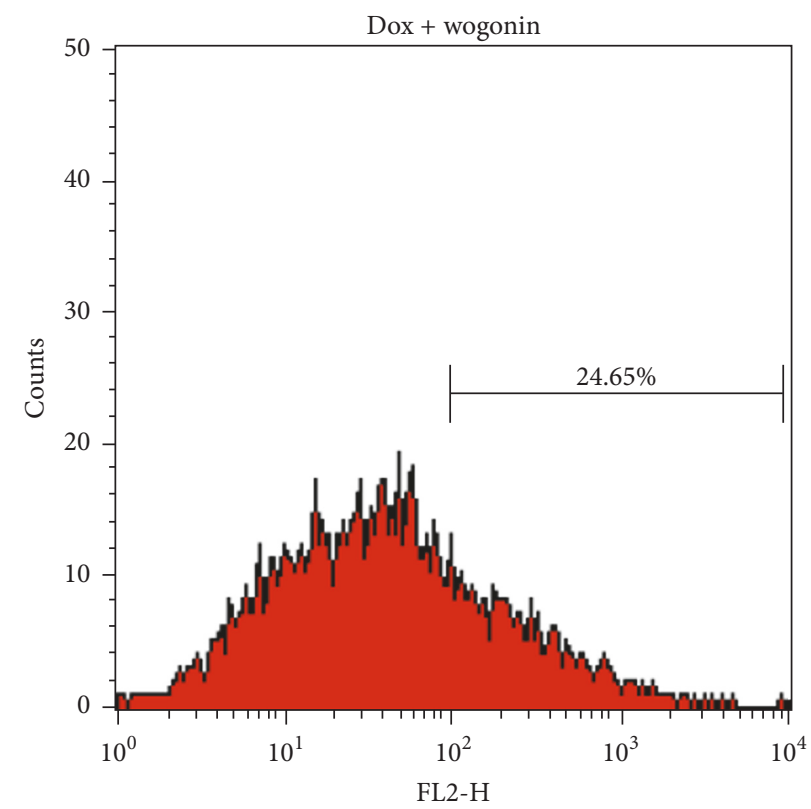

(c)

FIGURE 2: Wogonin rescued the loss of the mitochondrial membrane potential in Tet-On A $\beta_{42}$-GFP SH-SY5Y cells. A $\beta_{42}$-GFP SH-SY5Y cells were incubated with/without $10 \mu \mathrm{M}$ wogonin for one day at a density of $1 \times 10^{5}$, and then cells were induced with $10 \mu \mathrm{g} / \mathrm{mL}$ doxycycline (Dox) to express $\mathrm{A} \beta_{42}$ for five days. The cells were treated with vehicle as a control, and the loss of $\Delta \psi m$ was measured by JC-1 staining with a flow cytometer. The treatments included (a) control, (b) Dox $(10 \mu \mathrm{g} / \mathrm{mL})$, and (c) Dox with wogonin $(10 \mu \mathrm{M})$.

Detection System 1) and counterstained with hematoxylin (Novolink Polymer Detection System 1) following supplier's protocol.

2.12. Animal Model. C57BL/6 Non-Tg wild-type mice and homozygous $3 \mathrm{xTg}-\mathrm{AD}$ transgenic mice harboring human $\mathrm{PS}_{\mathrm{M} 146 \mathrm{~V}}$, human $\mathrm{APP}_{\text {Swe }}$, and human $\tan _{\mathrm{P} 301 \mathrm{~L}}$ [25] were bred and maintained in the animal facility at National Taiwan Normal University (NTNU) under specific pathogen-free conditions in accordance with the Institutional Guidelines of the Animal Care and Use Committee at NTNU. Three groups of mice were used and injected [intraperitoneally (i.p.)] with the vehicle or test compounds every other day from the 8th week to the 24th week of age. The first group (8 wild-type mice) and second group (8 3xTg-AD mice) were injected (i.p.) with dimethyl sulfoxide (DMSO), and the third group (8 3xTg-AD mice) was injected (i.p.) with wogonin $(10 \mathrm{mg} / \mathrm{kg})$. 


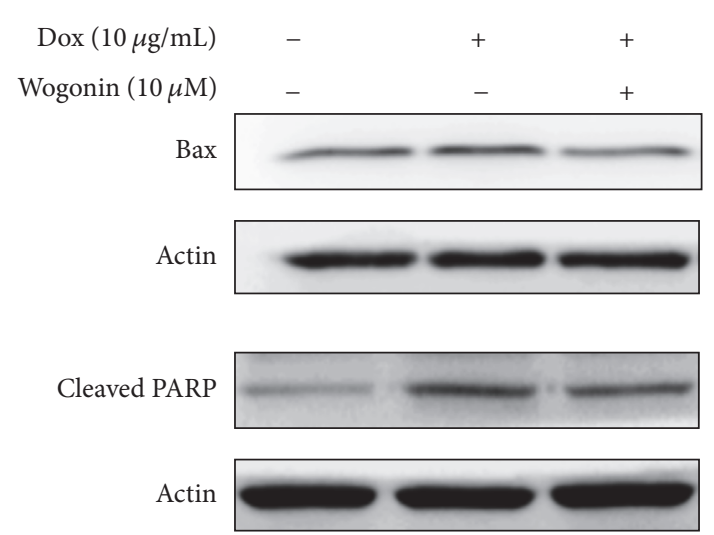

(a)

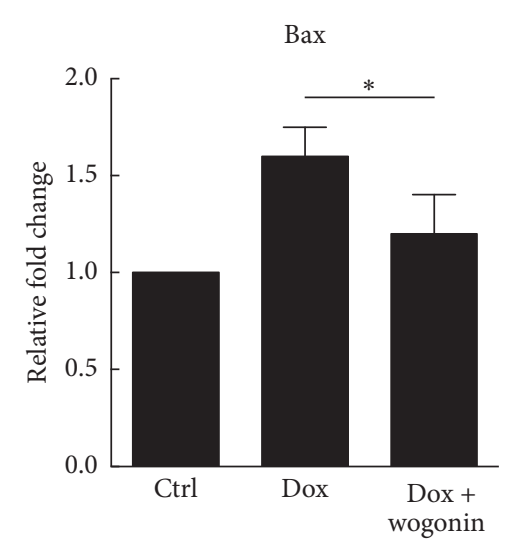

(b)

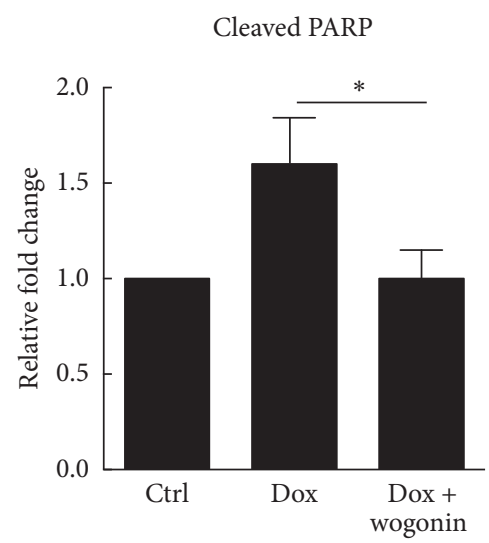

(c)

FIGURE 3: Wogonin decreased the expression levels of Bax and cleaved PARP in Tet-On A $\beta_{42}$-GFP SH-SY5Y cells. (a) A $\beta_{42}$-GFP SH-SY5Y cells were pretreated with/without $10 \mu \mathrm{M}$ wogonin for one day, and then cells were induced by $10 \mu \mathrm{g} / \mathrm{mL}$ doxycycline (Dox) for five days. After treating with $10 \mu \mathrm{M}$ wogonin for one days, $3 \times 10^{5} \mathrm{~A} \beta_{42}$-GFP SH-SY5Y cells were induced with $10 \mu \mathrm{g} / \mathrm{mL}$ Dox for five days to analyze the expression levels of Bax and cleaved poly (ADP-ribose) polymerase (PARP) by western blotting. Quantitative analyses of the levels of Bax (b) and cleaved PARP (c) were conducted with ImageJ respectively, and actin was used as a loading control. The results are shown as mean \pm SEM, $n=3,{ }^{*} p<0.05$.

The animals were examined by using behavioral tasks: (a) the Morris water maze test when the animals were 16- and 24week-old, (b) spontaneous alternation behavior Y-test when they were 24 weeks old, and (c) the novel object recognition task test when they were 23 weeks old. After completion of the behavioral tasks, the mice were sacrificed, and their brain tissues were homogenized with PBS and protease inhibitors for western blot and immunohistochemistry analyses. The body weights of the animals were measured every two weeks from the 6 th to 24 th week of age.

2.13. Data Analysis. All data are expressed as mean \pm SEM, and the statistical analyses were carried out using one-way ANOVA followed by Tukey's post hoc tests. Differences were considered statistically significant at $p<0.05$.

\section{Results}

3.1. Wogonin Suppressed the $A \beta_{42}$-Induced Amyloidogenic Pathway. To examine the half maximal inhibitory concentration $\left(\mathrm{IC}_{50}\right)$ of wogonin, Tet-On A $\beta_{42}$-GFP SH-SY5Y neuroblastoma cells were cultured in the absence and presence of wogonin at various concentrations (6.25-200 $\mu \mathrm{M})$. As shown in Figure $1(\mathrm{a})$, the $\mathrm{IC}_{50}$ of wogonin was about $100 \mu \mathrm{M}$ determined by MTT assay. The deficit in cholinergic system has been found in AD patients and associated with memory deficits [26]. Subsequently, acetylcholinesterase (AChE) inhibitors were used for symptomatic treatment of AD [27]. In Figure 1(b), AChE activity was significantly inhibited in the presence of wogonin $(10 \mu \mathrm{M})$. The amyloidogenic pathway results in $\mathrm{A} \beta_{42}$ assembly, which is the main source of the toxicity of neurons. Wogonin $(10 \mu \mathrm{M})$ inhibited $\mathrm{A} \beta_{42}$ oligomers species by performing dot-blot assay (Figure 1(c)). Here, we examined $\mathrm{A} \beta_{42}$ fibrillization by Thioflavin $\mathrm{T}$ (ThT) assay in the absence and presence of wogonin (1 and $10 \mu \mathrm{M})$. Data showed that $10 \mu \mathrm{M}$ wogonin significantly inhibited $\mathrm{A} \beta$ fibrillization (Figure 1(d)). To examine whether wogonin disrupts $\mathrm{A} \beta_{42}$ assembly in the starting time point, photoinduced cross-linking of unfolded protein (PICUP) was performed in the presence of wogonin. We found that $10 \mu \mathrm{M}$ wogonin potently disrupted $\mathrm{A} \beta_{42}$ assembly (Figure $1(\mathrm{e})$ ). These data indicated that wogonin interfered with $\mathrm{A} \beta_{42}$ oligomerization and fibrillization in vitro.

3.2. Wogonin Attenuated $A \beta_{42}$-Induced Apoptosis. In order to examine whether wogonin protects Tet-On $\mathrm{A} \beta_{42}$-GFP $\mathrm{SH}-\mathrm{SY} 5 \mathrm{Y}$ cells against mitochondria-mediated apoptosis, the effects of wogonin on the mitochondrial potential $(\Delta \psi m)$ of $\mathrm{A} \beta_{42}$-GFP SH-SY5Y cells were examined. The induced cells exhibited a $27.9 \%$ decrease in $\Delta \psi m$ compared to that of uninduced cells (Figures 2(a) and 2(b)), and pretreatment with wogonin $(10 \mu \mathrm{M})$ resulted in $11.4 \%$ decrease (Figure $2(\mathrm{c})$ ).

Furthermore, the expression levels of mitochondrial function biomarkers, such as Bax, were investigated by western blot analysis. In $\mathrm{A} \beta_{42}$-GFP-expressing cells, the expression level of Bax was increased to 1.6-fold compared to that of control cells, and it decreased to 1.2-fold after treatment with $10 \mu \mathrm{M}$ wogonin (Figures 3(a) and 3(b)).

Because wogonin reduced the $\Delta \psi m$, the effects of wogonin on the activation of cleaved PARP were examined. As shown in Figure 3 , the treatment of $\mathrm{A} \beta_{42}$-GFP-expressing cells with $10 \mu \mathrm{g} / \mathrm{mL}$ Dox increased the level of cleaved PARP by 1.5 -fold, and treatment with wogonin $(10 \mu \mathrm{M})$ decreased the level of cleaved PARP to 1.0-fold (Figure 3(c)). These findings suggest that wogonin alleviated the apoptosis activation of that which was induced by $\mathrm{A} \beta_{42}$ cytotoxicity.

3.3. Wogonin Increased Neurite Outgrowth. In the $\mathrm{A} \beta_{42}$-GFP SH-SY5Y cells treated with $10 \mu \mathrm{g} / \mathrm{mL}$ Dox to induce $\mathrm{A} \beta_{42^{-}}$ GFP expression, neurite length was less than $160 \mu \mathrm{m}$ from the soma (Figures 4(a) and 4(b)), and the number (mean \pm standard error) of intersections was $8.3 \pm 2.3$. After wogonin 


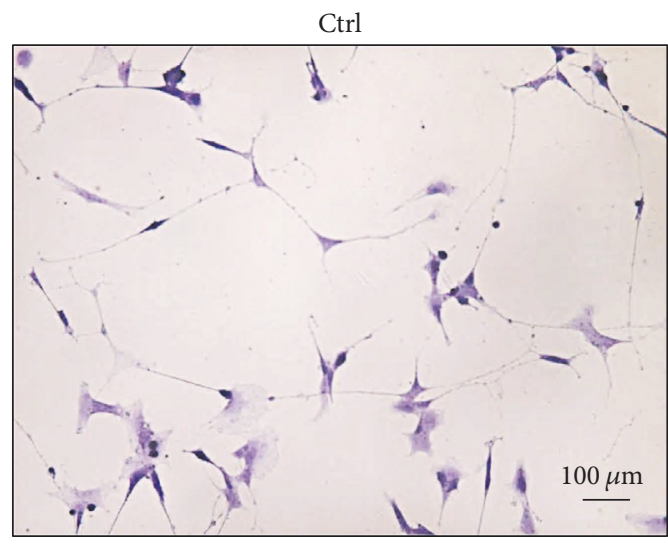

(a)

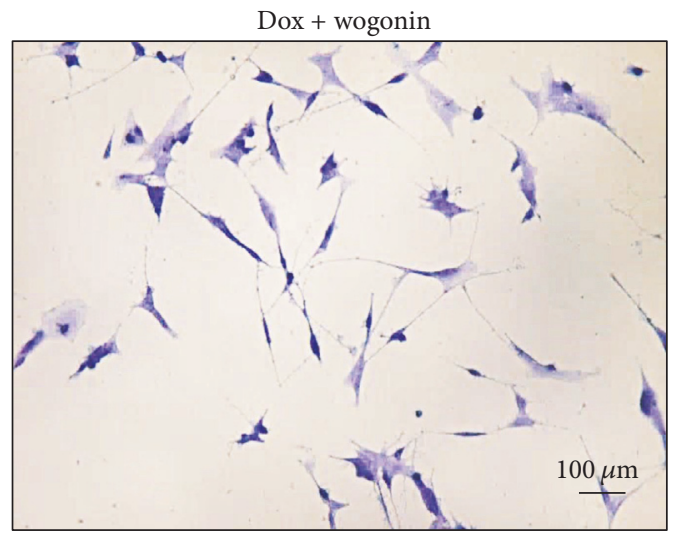

(c)

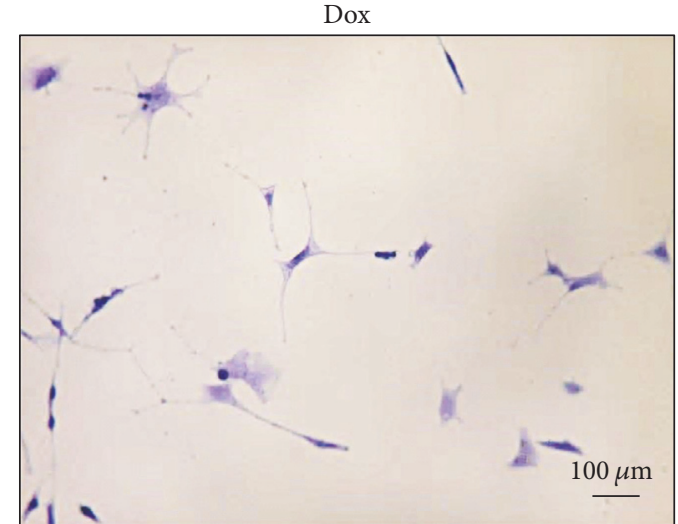

(b)

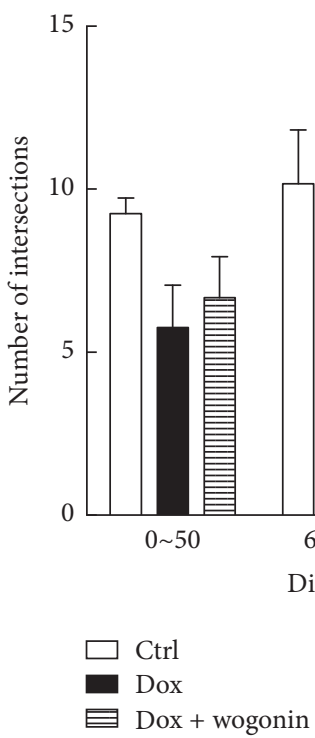

(d)

FIGURE 4: Wogonin improved neurite outgrowth in Tet-On A $\beta_{42}$-GFP SH-SY5Y cells. A $\beta_{42}$-GFP SH-SY5Y cells at a density of $5 \times 10^{4}$ were pretreated with $10 \mu \mathrm{M}$ wogonin for one day, which was followed by the addition of $10 \mu \mathrm{g} / \mathrm{mL}$ Dox in order to induce A $\beta_{42}$-GFP expression for five days. The cells were treated with vehicle as a control, and cell morphology of control (a), Dox (b), and Dox with wogonin (c) was examined by Sholl analysis to quantify neurite length and complexity. The results are shown as mean \pm SEM, $n=3$. Scale bar: $100 \mu$ m.

$(10 \mu \mathrm{M})$ treatment, the neurite length and the number of intersections increased to $200 \mu \mathrm{m}$ and $11.7 \pm 0.7$ (Figures 4(c) and $4(\mathrm{~d})$ ), respectively. These findings indicate that wogonin significantly increased the neurite outgrowth and complexity of $\mathrm{AD}$ cells.

3.4. Wogonin Ameliorated the Memory Deficit in $3 x \mathrm{Tg}-A D$ Transgenic Mice. Based on previous report, the $\mathrm{LD}_{50}$ of wogonin was found to be $3.9 \mathrm{~g} / \mathrm{kg}$ [28], and we used the dose of wogonin at $10 \mathrm{mg} / \mathrm{kg}$, for i.p. injection from 8 th week to 24 th week of age. The body weights of the $3 x \mathrm{Tg}-\mathrm{AD}$ transgenic mice did not differ from those of the control mice significantly (Figure 5(a)). In order to investigate whether wogonin rescues the memory deficit in $3 x \mathrm{Tg}-\mathrm{AD}$ mice, a Morris water maze experiment was carried out in order to evaluate hippocampal-dependent reference memory in the 16- and 24-week-old mice. The platform was removed in order to perform a probe trial by recording the path length and time spent in the quadrants. The results indicated that wogonin-treated AD mice spent significantly more time in the targeted quadrant than the vehicle-treated $\mathrm{AD}$ mice at 16 th and 24 th week (1.4-fold and 1.5-fold, resp.). These findings suggest that wogonin markedly ameliorated the memory impairments of AD mice (Figures 5(b) and 5(c)).

The novel object recognition test, which involves the frontal cortex, entorhinal cortex, and hippocampus, was employed to examine short-term memory. The results suggested that $\mathrm{AD}$ mice treated with vehicle did not preferentially explore the novel object, and the discrimination index was less than 50\%. In contrast, wogonin-treated AD mice displayed $62.8 \%$ increment in discrimination index compared to that of $\mathrm{AD}$ mice for the novel object at the 23rd week (Figure 6(a)). Y-maze test was conducted in order to examine short-term and working memory. The 


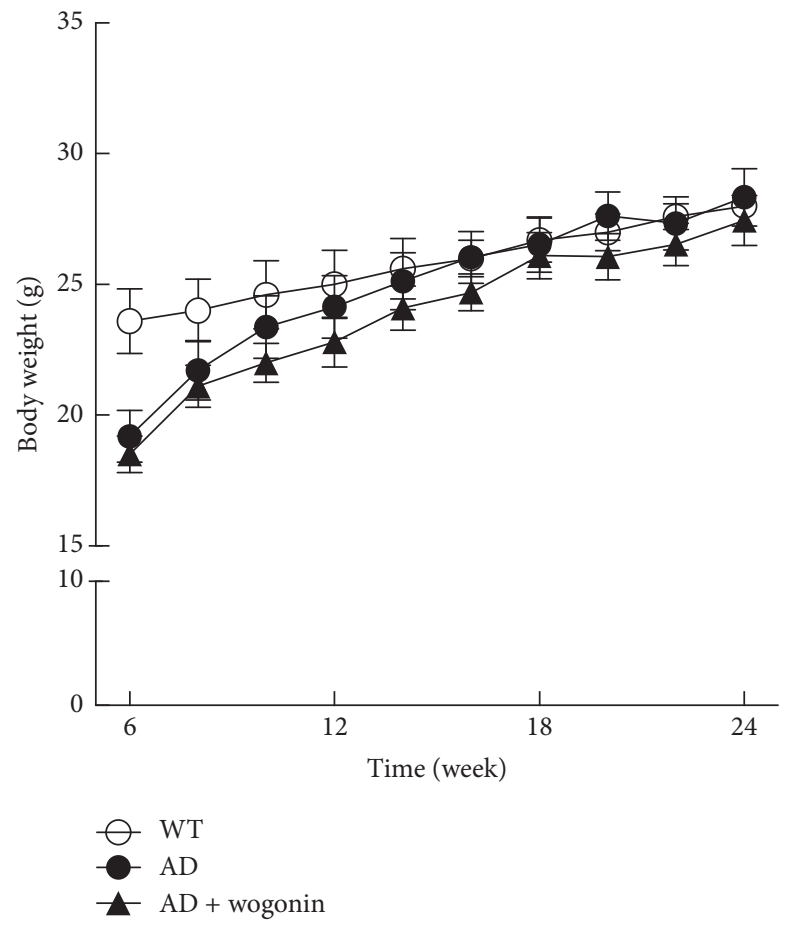

(a)
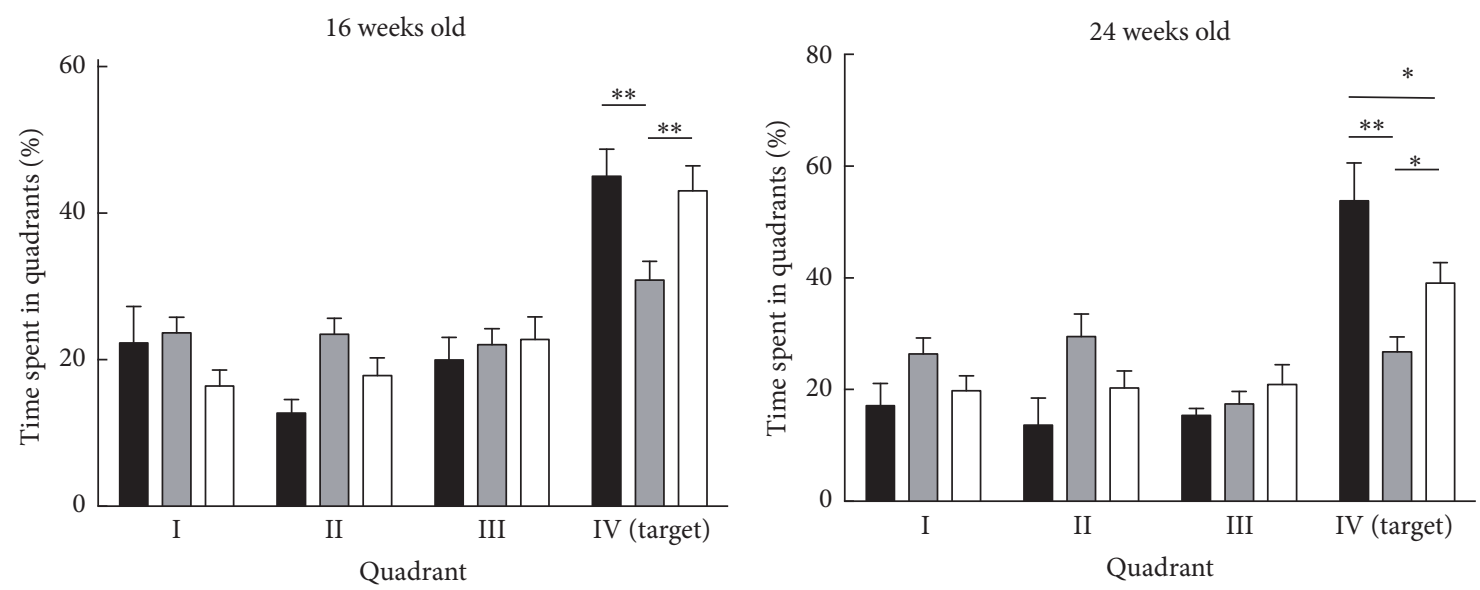

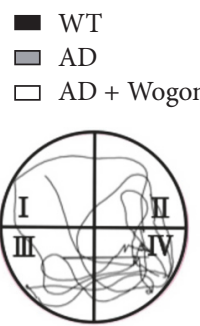

WT

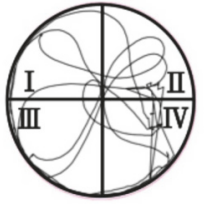

$\mathrm{AD}$

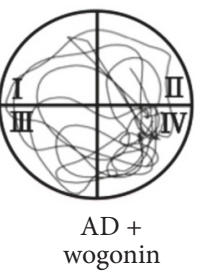

(b)

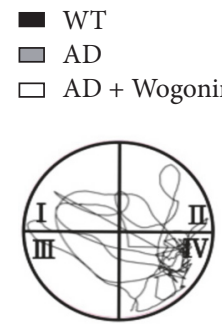

WT

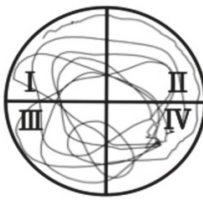

$\mathrm{AD}$

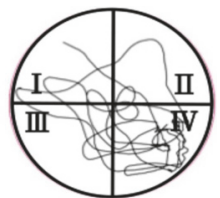

$\mathrm{AD}+$

wogonin

(c)

FIGURE 5: Wogonin alleviated the memory deficits in eight 3xTg-AD mice. Mice were injected [intraperitoneally (i.p.)] with $10 \mathrm{mg} / \mathrm{kg}$ wogonin every other day from the 8 th to the 24 th week of age. (a) The body weights of the mice were measured every 2 weeks from the 6th to the 24th week of age. (b) 16-week-old mice were subjected to water maze experiments without platform, and the time spent in quadrants was measured. Representative path tracing was presented in the lower panel. (c) Probe trial of water maze experiments was conducted in the 24-week-old mice, and the time spent in quadrants was measured. Representative path tracing was presented in the lower panel, and the results are shown as mean $\pm \mathrm{SEM}, n=8,{ }^{*} p<0.05,{ }^{* *} p<0.01$. 


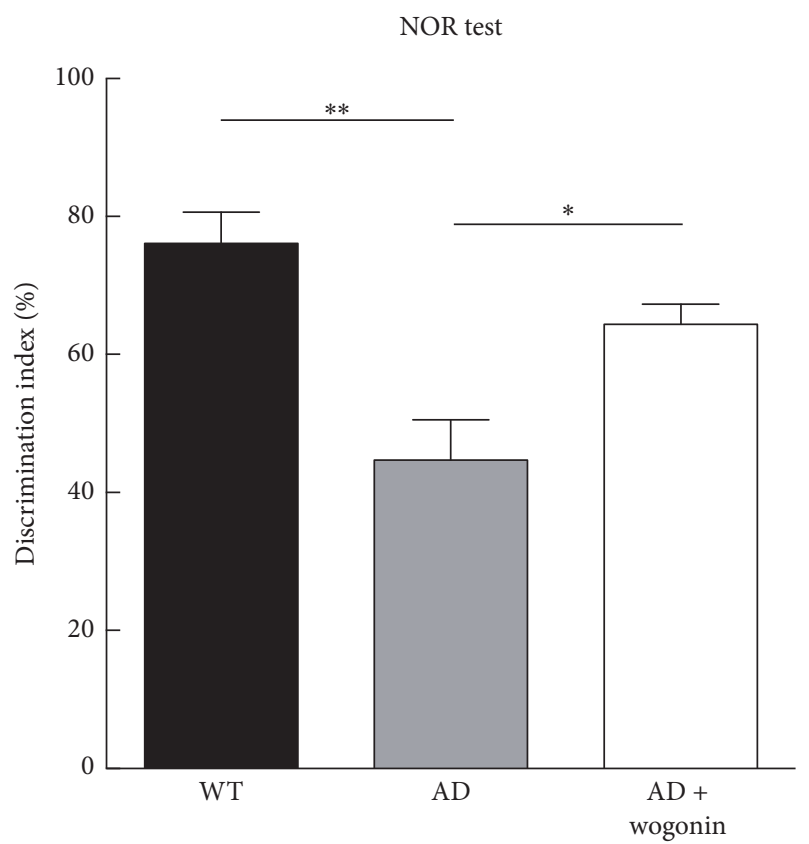

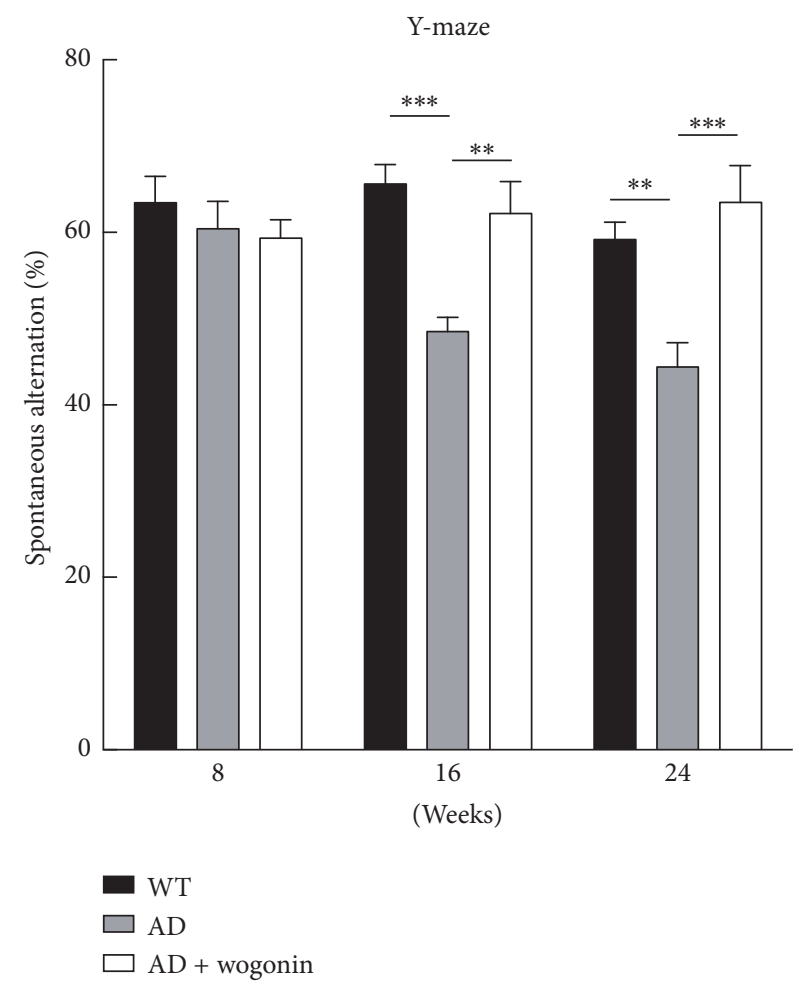

(b)

FIgURE 6: Wogonin treatment attenuated the behavior on the novel object recognition task and Y-maze test in eight 3xTg-AD mice. 3xTg$\mathrm{AD}$ mice were applied $10 \mathrm{mg} / \mathrm{kg}$ wogonin every other day from the 8 th to the 24 th week of age by intraperitoneal injection. (a) Novel object recognition (NOR) experiments were performed in the 23-week-old mice. The discrimination index was calculated as a percentage ratio of $T_{B} /\left(T_{A}+T_{B}\right) \times 100$. (a) Familiar object. (b) Novel object. (b) Spontaneous alternation behavior Y-maze tests were performed in the 8-, 16-, and 24 -week-old mice. Alternation $(\%)=[$ (number of alternations) $/($ total arm entries -2$)] \times 100$. All of the values are shown as mean \pm SEM, $n=8,{ }^{*} p<0.05,{ }^{* *} p<0.01$, and ${ }^{* * *} p<0.001$.

results indicated that vehicle-treated $\mathrm{AD}$ mice displayed a decrement of spontaneous alternation behavior, whereas wogonin-treated AD mice showed a 1.3 -fold and 1.4-fold increment in spontaneous alternation at the 16th and 24th week, respectively (Figure 6(b)). These results suggest that wogonin significantly recovered the short-term memory of $\mathrm{AD}$ mice.

3.5. Wogonin Attenuated the Activation of the Amyloidogenic Pathway in the Cerebral Tissues of $3 x \mathrm{Tg}$-AD Mice. The expression levels of APP and BACE1, which are related to the amyloidogenic pathway, were investigated in the cerebral tissues of $\mathrm{AD}$ mice in order to examine whether wogonin treatment inhibits the amyloidogenic pathway. Western blot analyses demonstrated that the expression level of BACE1 in vehicle-treated $A D$ mice was 4.0-fold (Figures $7(a)$ and 7(b)), higher than that of wild-type mice, but the level in wogonintreated AD mice was only 1.5 -fold.

In addition, the expression levels of phospho-Tau and total Tau were examined. The levels of phospho-Tau and total Tau in the vehicle-treated AD mice were 3.0- and 3.4-fold, respectively, higher than those of wild-type mice. Consistently, wogonin decreased the expression levels of phosphoTau and total Tau to 1.3- and 1.5-fold, respectively (Figures 7(c), 7(d), and 7(e)), than those of AD mice. In addition, high molecular weight oligomers $(>40 \mathrm{kDa})$ of wogonin-treated $\mathrm{AD}$ mice were decreased to 0.7 -fold compared to that of vehicle-treated $A D$ mice (Figures $8(a)$ and $8(b)$ ). These results strongly suggested that wogonin profoundly suppressed the amyloidogenic pathway, as well as Tau and phosphorylated Tau protein, in the cerebra of $\mathrm{AD}$ mice.

Because the formation of amyloid plaque is a hallmark of $\mathrm{AD}$, we used immunohistochemical analysis to determine whether wogonin decreases $A \beta$ deposition in the brain of $\mathrm{AD}$ mice. $\mathrm{A} \beta$ immunoreactive plaques were observed using the 6E10 antibody in the cortex and hippocampus of vehicle-treated $\mathrm{AD}$ mice at 24th week of age, and the treatments with wogonin reduced the number and the area of $\mathrm{A} \beta$ immunoreactive plaques compared to that of control group (Figure 9). It indicated that wogonin attenuated $A \beta$ aggregation in the cortex and hippocampus of $\mathrm{AD}$ mice at 24th week.

\section{Discussion}

The amyloid cascade hypothesis that $\mathrm{A} \beta$ aggregates form amyloid plaque, neurofibrillary tangle, and lead to neuronal death is one of pathogeneses in AD [29]. However, it has 


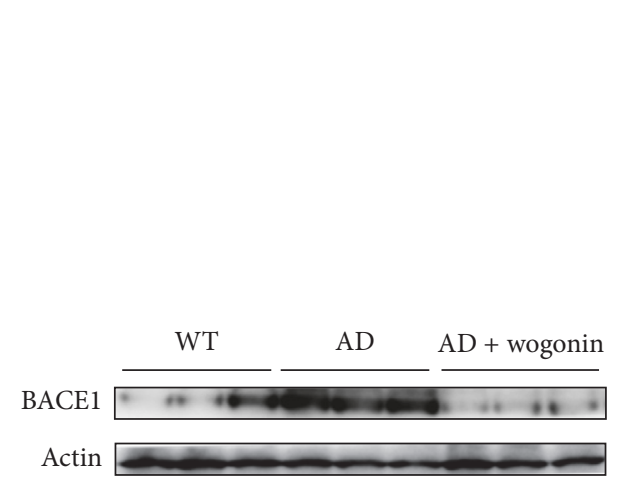

(a)

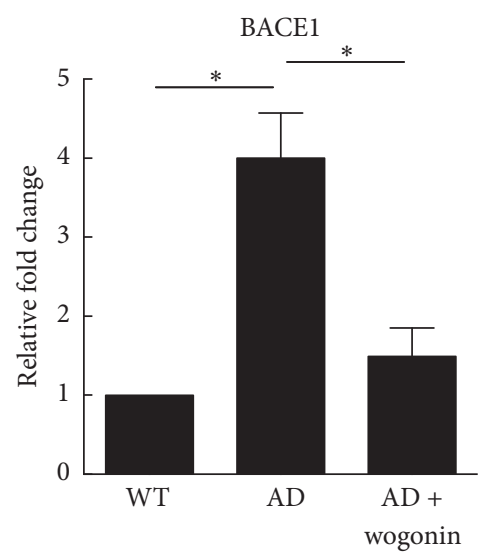

(b)

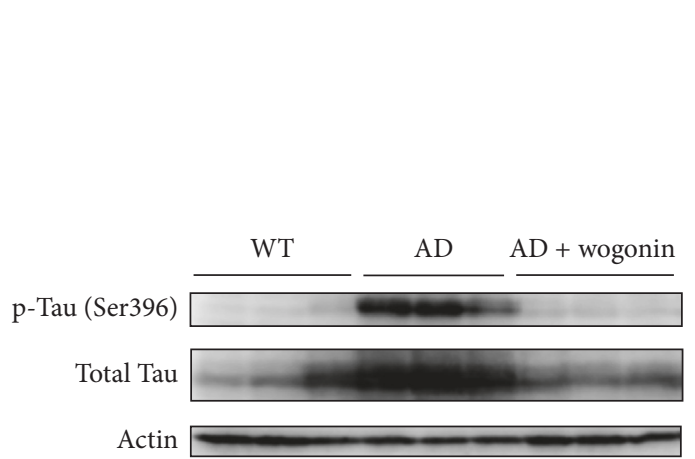

(c)

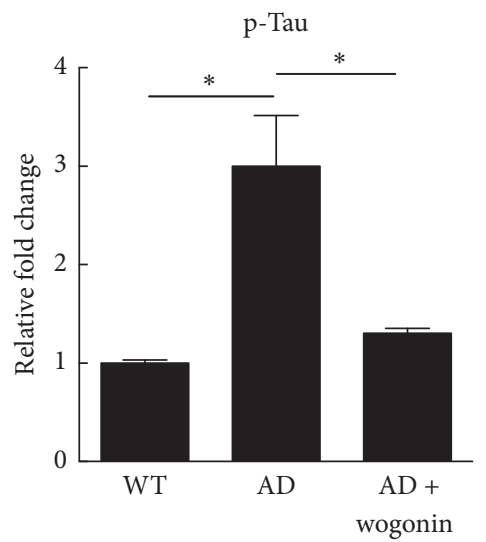

(d)

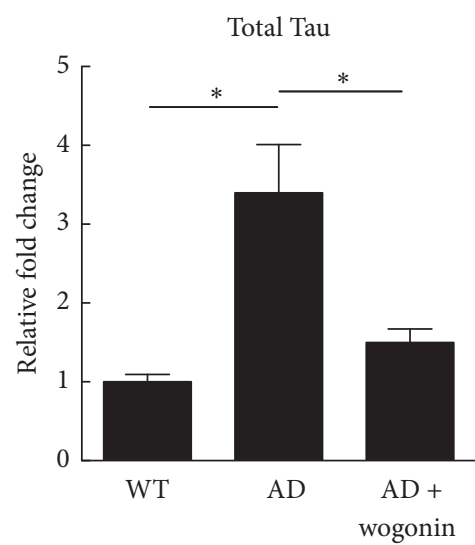

(e)

FIGURE 7: Wogonin decreased the levels of BACE1, p-Tau, and total Tau proteins in the cerebral tissue of three 3xTg-AD mice. Mice were given intraperitoneal injection with vehicle/wogonin $(10 \mathrm{mg} / \mathrm{kg})$ every other day from the 8 th to the 24 th week of age, and mice were sacrificed for western blot analysis in the 24th week of age. (a) The expression level of BACE1 in the cerebra of mice was measured using western blot analysis in the 24-week-old mice. (b) Quantitative analysis of the level of BACE1 was executed with ImageJ. (c) The cerebellar extracts of 3xTg-AD mice were immunostained against p-Tau and Tau protein in the 24-week-old mice. Relative intensity of p-Tau (d) and total Tau (e) was performed with ImageJ. Actin was used as a loading control. The results are shown as mean \pm SEM, ${ }^{*} p<0.05$.

shown that soluble oligomers of $\mathrm{A} \beta$ peptide are the key factors that contribute to neurotoxicity, synaptic loss, and memory impairment in $\mathrm{AD}[30-34]$, and inhibition of $\mathrm{A} \beta$ aggregates attenuates the toxicity $[35,36]$.

Therefore, one of therapeutic strategies for $\mathrm{AD}$ is to interfere with $\mathrm{A} \beta$ aggregates. In the present study, the oligomeric assembly of $A \beta_{42}$ peptide and the level of $A \beta$ fibril formation are disturbed by wogonin in vitro, suggesting that wogonin inhibits nucleated oligomerization and seeding mediated aggregation. As cholinergic deficit is observed in the early stages of $\mathrm{AD}$ and associated with memory deficits, $10 \mu \mathrm{M}$ wogonin $\left(1 / 10 \mathrm{IC}_{50}\right)$ significantly inhibited $\mathrm{AChE}$ activity in Tet-On A $\beta_{42}$-GFP SH-SY5Y neuroblastoma cells, suggesting that wogonin disrupted the activation of $\mathrm{AChE}$ induced by $\mathrm{A} \beta_{42}$.

Several animal models have been generated to develop $\mathrm{AD}$-like pathology in order to study the disease modifying effects of potential treatment of $\mathrm{AD}$. In the present study, we examined the effects of wogonin on the cerebral tissues of 3xTg-AD mice, overexpressing human $\mathrm{APP}_{\text {Swe }}$, human
$\operatorname{tau}_{\mathrm{P} 301 \mathrm{~L}}$, and human $\mathrm{PS} 1_{\mathrm{M} 146 \mathrm{~V}}$ mutation. This model demonstrates an age-dependent onset of $\mathrm{AD}$ with deficits in synaptic plasticity and cognition correlating with the deposition of intracellular $\mathrm{A} \beta$ in the early stage, extracellular amyloid plaques at 6 months beginning with the frontal cortex, and then expanded to the hippocampus, as well as other cortical regions, and neurofibrillary tangles observed in moderate to severe stages $[25,37,38]$. Here, we show that wogonin inhibits amyloid plaque burden in the cortex and hippocampus of $3 x$ Tg-AD mice. Furthermore, A $\beta$ oligomers are dramatically decreased by wogonin administration in the hippocampus extraction of $3 \mathrm{xTg}-\mathrm{AD}$ mice.

It has been demonstrated that inhibition of amyloidogenic pathway by decreasing BACE1 alleviates amyloid pathology in mouse model of $\mathrm{AD}[39,40]$. We show that BACE1 expression is decreased by wogonin in vivo and in vitro model of $\mathrm{AD}$. Taken together, these date suggest that wogonin inhibits the amyloidogenic processing by decreasing BACE1 expression. 


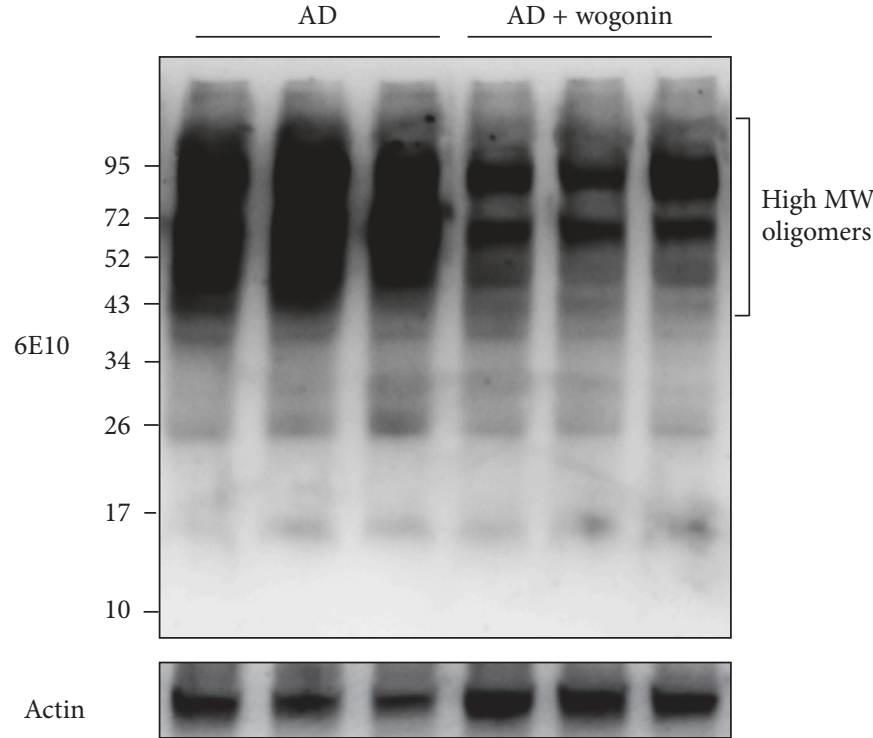

(a)

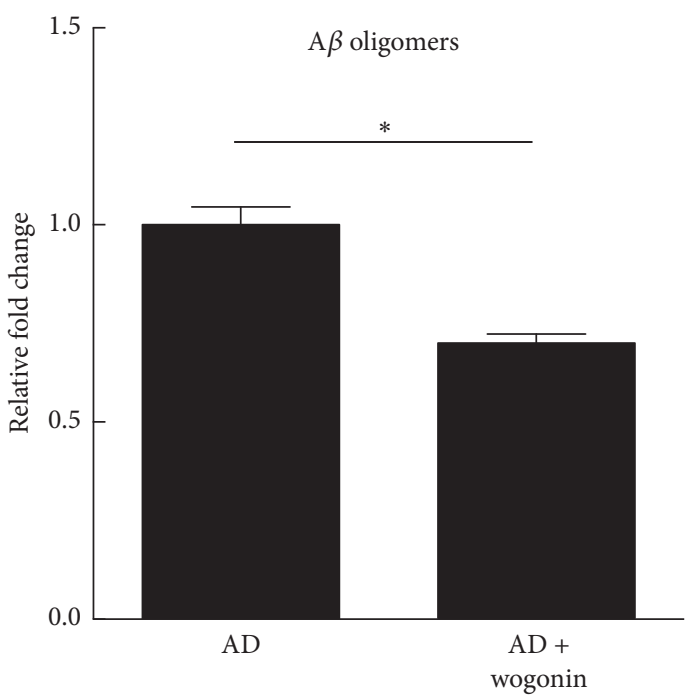

(b)

FIGURE 8: Wogonin decreased $\mathrm{A} \beta$ aggregates (high molecular weight oligomers) in the cerebral tissue of three $3 \mathrm{xTg}-\mathrm{AD}$ mice. $3 \mathrm{xTg}$-AD mice were given injection intraperitoneally with vehicle/wogonin $(10 \mathrm{mg} / \mathrm{kg})$ every other day from the 8th to the 24th week of age. Mice were sacrificed when they were 24 weeks old, and cerebellar extracts were subjected to western blot analysis. (a) Aggregation of A $\beta$ on cerebellar extracts of 3xTg-AD mice was measured by using a 6E10 antibody. (b) Relative intensity of A $\beta$ aggregates was presented with ImageJ. Actin was used as a loading control. The results are shown as mean \pm SEM, ${ }^{*} p<0.05$.
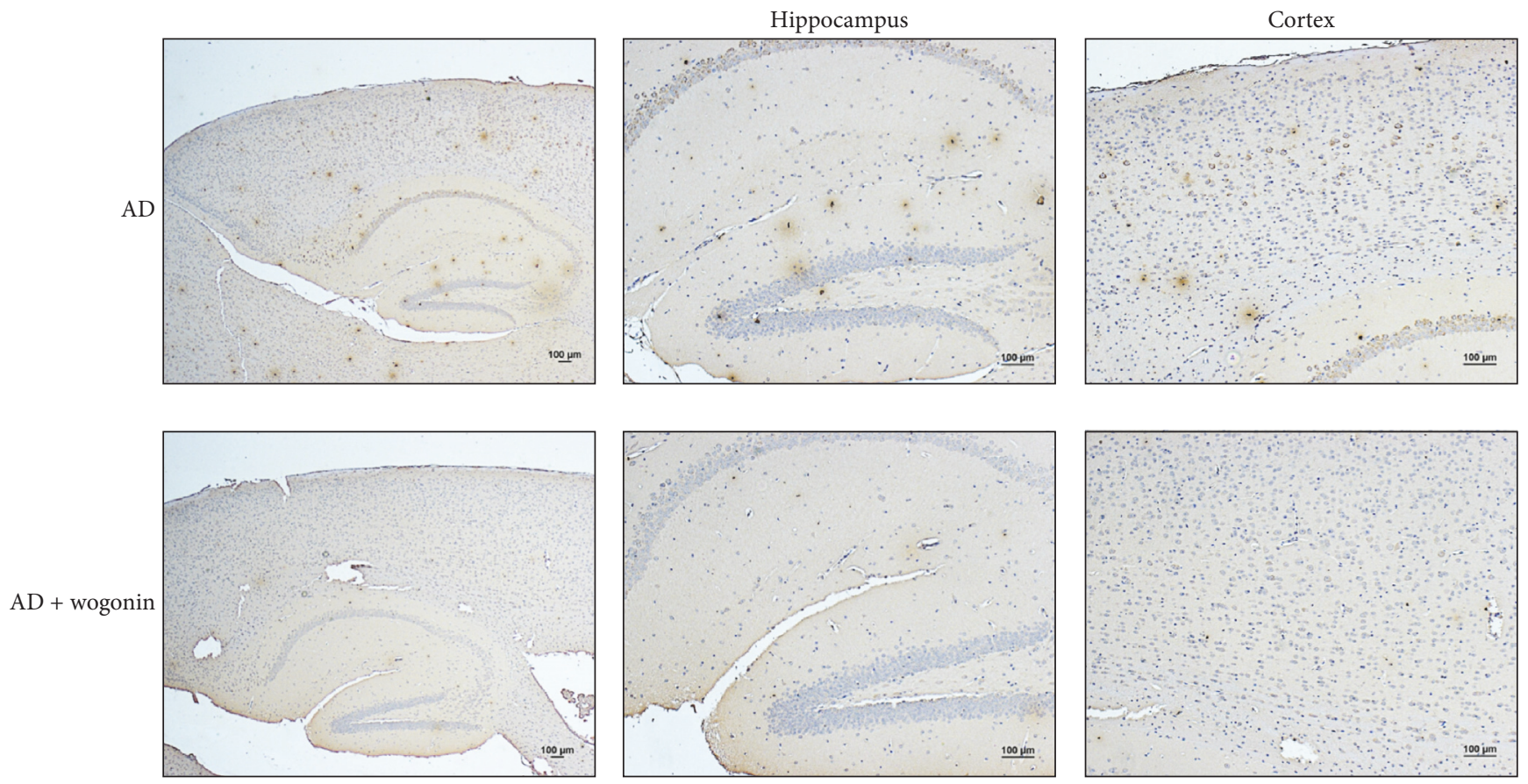

FIGURE 9: Treatment with wogonin reduces amyloid plaques in the cortex and hippocampus in 3xTg-AD mice. 3xTg-AD mice were applied with vehicle $/ 10 \mathrm{mg} / \mathrm{kg}$ wogonin (i.p. injection) every other day from the 8 th to the 24 th week of age. Mice were sacrificed at the 24 th week of age, and paraffin-embedded brain sections were subjected to immunohistochemical staining. (a) Immunohistochemical staining of sections from 24-week-old 3xTg-AD mice was stained with A $\beta$ (6E10) antibodies in the cortex and hippocampus. Scale bar: $100 \mu \mathrm{m}$. 
Neuronal death underlies the symptoms of several neurodegenerative diseases, including Parkinson's disease and Alzheimer's disease [41]. Several studies indicate that $\mathrm{A} \beta$ localizes to mitochondria [11, 15, 42], and the accumulation of intracellular $\mathrm{A} \beta$ has been known to result in neuronal apoptosis, which is associated with mitochondrial dysfunction [11, 17, 43-47]. Bcl-2 family proteins are involved in mitochondrial related apoptosis by regulating the mitochondrial membrane permeability. Bax, a proapoptotic protein, is localized to the mitochondrial outer membrane and increases membrane permeability, which is resulting in cell death [48, 49]. In the present study, protein level of Bax is decreased by wogonin in vitro and in vivo model of AD. Furthermore, wogonin inhibits the loss of mitochondrial membrane potential induced by $\mathrm{A} \beta$ in Tet-On $\mathrm{A} \beta_{42}$-GFP SH-SY5Y cells. Activation of apoptotic pathway in response to mitochondrial dysfunction in Tet-On A $\beta_{42}$-GFP SH-SY5Y cells is decreased in the presence of wogonin by suppressing cleaved caspase- 9 and cleaved PARP.

Progressive decline in cognition is most obvious symptom in AD patient. Several behavioral tests are used to evaluate cognitive ability in mice. In this study, wogonin improves the spatial reference memory measured by Morris water maze at the age of 16 weeks and 24 weeks old. However, the spatial reference memory has no difference between WT mice and wogonin-treated mice at the age of 16 weeks old, but it is impaired at the age of 24 weeks. It is indicating that reference memory impairment is delayed by wogonin in 3xTg AD mice. On the other hand, the working memory is measured by Y-maze and novel object recognition test. Wogonin alleviates the working memory impairment in 3xTg $\mathrm{AD}$ mice.

It has been demonstrated that $\mathrm{A} \beta$ can induce cognitive impairment and trigger mitochondria-mediated apoptosis by upregulation of $\operatorname{Bax}[50,51]$. Here we found that wogonin inhibits the expression levels of BACE1, A $\beta$ oligomer, Bax, and cleaved caspase-9, suggesting that wogonin improves cognition through inhibition of $\mathrm{A} \beta$ oligomerization and mitochondria-mediated apoptosis in 3xTg AD mice.

Taken together, wogonin has various neuroprotective and neurotrophic activities, including inducing neurite outgrowth. In addition, wogonin alleviates the cognitive deficits of 3xTg AD mice. Therefore, the wogonin-regulated APP processing serves as a neuroprotective activity that might contribute to the treatment of $\mathrm{AD}$.

\section{Conflicts of Interest}

There are no conflicts of interest in this study.

\section{Acknowledgments}

The authors thank Dr. Guey-Jen Lee-Chen and Dr. Hsiu-Mei Hsieh-Li for Tet-On A $\beta_{42}$-GFP cells and triple transgenic mice, respectively. The authors also thank Dr. Hsuan-Yuan Lin for consultation and editing on an earlier version of this manuscript. This work was supported by the Ministry of
Science and Technology (Grants MOST 103-2320-B-003-001MY3, MOST 105-2325-B-003-002, and MOST 105-2320-B003-001) and by National Taiwan Normal University, Taipei, Taiwan (106T3040D0).

\section{References}

[1] D. J. Selkoe, "Alzheimer's disease," Cold Spring Harbor Perspectives in Biology, vol. 3, no. 7, pp. 1-16, 2011.

[2] H. Zempel, J. Luedtke, Y. Kumar et al., "Amyloid- $\beta$ oligomers induce synaptic damage via Tau-dependent microtubule severing by TTLL6 and spastin," The EMBO Journal, vol. 32, no. 22, pp. 2920-2937, 2013.

[3] S. L. Cole and R. Vassar, "The Alzheimer's disease $\beta$-secretase enzyme, BACE1," Molecular Neurodegeneration, vol. 2, no. 1, article 22, 2007.

[4] R. Vassar, D. M. Kovacs, R. Yan, and P. C. Wong, "The $\beta$ secretase enzyme BACE in health and Alzheimer's disease: Regulation, cell biology, function, and therapeutic potential," Journal of Neuroscience, vol. 29, no. 41, pp. 12787-12794, 2009.

[5] F. M. LaFerla, K. N. Green, and S. Oddo, "Intracellular amyloid$\beta$ in Alzheimer's disease," Nature Reviews Neuroscience, vol. 8, no. 7, pp. 499-509, 2007.

[6] L. N. Zhao, H. Long, Y. Mu, and L. Y. Chew, "The toxicity of amyloid $\beta$ oligomers," International Journal of Molecular Sciences, vol. 13, no. 6, pp. 7303-7327, 2012.

[7] D. R. Thal, J. Walter, T. C. Saido, and M. Fändrich, "Neuropathology and biochemistry of $\mathrm{A} \beta$ and its aggregates in Alzheimer's disease," Acta Neuropathologica, vol. 129, no. 2, pp. 167-182, 2015.

[8] X. Li, Y. Deng, F. Li, J. Shi, and Q. Gong, "Neuroprotective effects of sodium hydrosulfide against $\beta$-amyloid-induced neurotoxicity," International Journal of Molecular Medicine, vol. 38, no. 4, pp. 1152-1160, 2016.

[9] C. Galli, A. Piccini, M. T. Ciotti et al., "Increased amyloidogenic secretion in cerebellar granule cells undergoing apoptosis," Proceedings of the National Academy of Sciences of the United States of America, vol. 95, no. 3, pp. 1247-1252, 1998.

[10] Y. Li, W. Zhou, Y. Tong, G. He, and W. Song, "Control of $\mathrm{APP}$ processing and $\mathrm{A} \beta$ generation level by BACE1 enzymatic activity and transcription," FASEB Journal, vol. 20, no. 2, pp. 285-292, 2006.

[11] M. Manczak, T. S. Anekonda, E. Henson, B. S. Park, J. Quinn, and P. H. Reddy, "Mitochondria are a direct site of A beta accumulation in Alzheimer's disease neurons: implications for free radical generation and oxidative damage in disease progression," Human Molecular Genetics, vol. 15, no. 9, pp. 14371449,2006

[12] J. X. Chen and S. S. Yan, "Role of mitochondrial amyloid- $\beta$ in Alzheimer's disease," Journal of Alzheimer's Disease, vol. 20, no. 2, pp. S569-S578, 2010.

[13] C. Cadonic, M. G. Sabbir, and B. C. Albensi, "Mechanisms of mitochondrial dysfunction in Alzheimer's disease," Molecular Neurobiology, 2015.

[14] K. Lunnon, Z. Ibrahim, P. Proitsi et al., "Mitochondrial dysfunction and immune activation are detectable in early Alzheimer's disease blood," Journal of Alzheimer's disease, vol. 30, no. 3, pp. 685-710, 2012.

[15] C. Caspersen, N. Wang, J. Yao et al., "Mitochondrial A $\beta$ : a potential focal point for neuronal metabolic dysfunction in 
Alzheimer's disease," The FASEB Journal, vol. 19, no. 14, pp. 2040-2041, 2005.

[16] Q. Q. Fu, L. Wei, J. Sierra et al., "Olfactory ensheathing cell-conditioned medium reverts A $\beta 25-35$-induced oxidative damage in SH-SY5Y cells by modulating the mitochondriamediated apoptotic pathway," Cellular and Molecular Neurobiology, 2016.

[17] J. W. Tan and M. K. Kim, "Neuroprotective effects of Biochanin A against $\beta$-amyloid-induced neurotoxicity in PC12 cells via a mitochondrial-dependent apoptosis pathway," Molecules, vol. 21, no. 5, article no. 548, 2016.

[18] H.-S. Kim, J.-H. Lee, J.-P. Lee et al., "Amyloid $\beta$ peptide induces cytochrome c release from isolated mitochondria," NeuroReport, vol. 13, no. 15, pp. 1989-1993, 2002.

[19] C. M. Rodrigues, S. Solá, R. Silva, and D. Brites, "Bilirubin and amyloid-beta peptide induce cytochrome $\mathrm{c}$ release through mitochondrial membrane permeabilization.", Molecular medicine, vol. 6, no. 11, pp. 936-946, 2000.

[20] H. Lee, Y. O. Kim, H. Kim et al., "Flavonoid wogonin from medicinal herb is neuroprotective by inhibiting inflammatory activation of microglia," The FASEB Journal, vol. 17, no. 13, pp. 1943-1944, 2003.

[21] H. Kim, Y. S. Kim, S. Y. Kim, and K. Suk, “The plant flavonoid wogonin suppresses death of activated C6 rat glial cells by inhibiting nitric oxide production," Neuroscience Letters, vol. 309, no. 1, pp. 67-71, 2001.

[22] Z. Gao, K. Huang, and H. Xu, "Protective effects of flavonoids in the roots of Scutellaria baicalensis Georgi against hydrogen peroxide-induced oxidative stress in HS-SY5Y cells," Pharmacological Research, vol. 43, no. 2, pp. 173-178, 2001.

[23] K. Ono, M. M. Condron, and D. B. Teplow, "Structureneurotoxicity relationships of amyloid $\beta$-protein oligomers," Proceedings of the National Academy of Sciences of the United States of America, vol. 106, no. 35, pp. 14745-14750, 2009.

[24] J. R. Holmes and A. Berkowitz, "Dendritic orientation and branching distinguish a class of multifunctional turtle spinal interneurons," Frontiers in Neural Circuits, vol. 8, no. November, 2014.

[25] S. Oddo, A. Caccamo, J. D. Shepherd et al., "Triple-transgenic model of Alzheimer's Disease with plaques and tangles: intracellular $\mathrm{A} \beta$ and synaptic dysfunction," Neuron, vol. 39, no. 3, pp. 409-421, 2003.

[26] E. J. Mufson, S. E. Counts, S. E. Perez, and S. D. Ginsberg, "Cholinergic system during the progression of Alzheimer's disease: Therapeutic implications," Expert Review of Neurotherapeutics, vol. 8, no. 11, pp. 1703-1718, 2008.

[27] J. Birks, "Cholinesterase inhibitors for Alzheimer's disease.," Cochrane database of systematic reviews (Online), no. 1, p. CD005593, 2006.

[28] M. C. Tai, S. Y. Tsang, L. Y. F. Chang, and H. Xue, “Therapeutic potential of wogonin: a naturally occurring flavonoid," CNS Drug Reviews, vol. 11, no. 2, pp. 141-150, 2005.

[29] J. A. Hardy and G. A. Higgins, "Alzheimer's disease: the amyloid cascade hypothesis," Science, vol. 256, no. 5054, pp. 184-185, 1992.

[30] P. Faucher, N. Mons, J. Micheau, C. Louis, and D. J. Beracochea, "Hippocampal injections of oligomeric amyloid $\beta$ peptide (1-42) induce selective working memory deficits and long-lasting alterations of ERK signaling pathway," Frontiers in Aging Neuroscience, vol. 7, article 245, 2016.
[31] M. P. Lambert, A. K. Barlow, B. A. Chromy et al., "Diffusible, nonfibrillar ligands derived from A $\beta 1-42$ are potent central nervous system neurotoxins," Proceedings of the National Academy of Sciences of the United States of America, vol. 95, no. 11, pp. 6448-6453, 1998.

[32] M. J. Rowan, I. Klyubin, Q. Wang, N. W. Hu, and R. Anwyl, "Synaptic memory mechanisms: Alzheimer's disease amyloid beta-peptide-induced dysfunction," Biochemical Society Transactions, vol. 35, part 5, pp. 1219-1223, 2007.

[33] D. M. Walsh, I. Klyubin, G. M. Shankar et al., "The role of cellderived oligomers of $A \beta$ in Alzheimer's disease and avenues for therapeutic intervention," Biochemical Society Transactions, vol. 33, no. 5, pp. 1087-1090, 2005.

[34] V. G. Ostapchenko, M. Chen, M. S. Guzman et al., "The Transient Receptor Potential Melastatin 2 (TRPM2) channel contributes to $\beta$-amyloid oligomer-related neurotoxicity and memory impairment," The Journal of Neuroscience, vol. 35, no. 45, pp. 15157-15169, 2015.

[35] L. Diomede, M. Romeo, A. Cagnotto et al., “The new $\beta$ amyloidderived peptide $A \beta 1-6 \mathrm{~A} 2 \mathrm{~V}$-TAT(D) prevents $\mathrm{A} \beta$ oligomer formation and protects transgenic C. elegans from $\mathrm{A} \beta$ toxicity," Neurobiology of Disease, vol. 88, pp. 75-84, 2016.

[36] A. Thapa, S. D. Jett, and E. Y. Chi, "Curcumin Attenuates Amyloid- $\beta$ Aggregate Toxicity and Modulates Amyloid- $\beta$ Aggregation Pathway," ACS Chemical Neuroscience, vol. 7, no. 1, pp. 56-68, 2016.

[37] R. Sterniczuk, M. C. Antle, F. M. LaFerla, and R. H. Dyck, "Characterization of the 3xTg-AD mouse model of Alzheimer's disease: part 2. Behavioral and cognitive changes," Brain Research, vol. 1348, pp. 149-155, 2010.

[38] S. F. Kazim, J. Blanchard, C.-L. Dai et al., "Disease modifying effect of chronic oral treatment with a neurotrophic peptidergic compound in a triple transgenic mouse model of Alzheimer's disease," Neurobiology of Disease, vol. 71, pp. 110-130, 2014.

[39] L. Schnöder, W. Hao, Y. Qin et al., "Deficiency of neuronal p38 $\alpha$ MAPK attenuates amyloid pathology in Alzheimer disease mouse and cell models through facilitating lysosomal degradation of BACE1," Journal of Biological Chemistry, vol. 291, no. 5, pp. 2067-2079, 2016.

[40] X. Wang, Y. Wang, J.-P. Hu et al., "Astragaloside IV, a Natural PPAR $\gamma$ Agonist, Reduces A $\beta$ Production in Alzheimer's Disease Through Inhibition of BACE1," Molecular Neurobiology, pp. 111, 2016.

[41] M. P. Mattson, "Apoptosis in neurodegenerative disorders," Nature Reviews Molecular Cell Biology, vol. 1, no. 2, pp. 120-129, 2000.

[42] P. J. Crouch, R. Blake, J. A. Duce et al., "Copper-dependent inhibition of human cytochrome $c$ oxidase by a dimeric conformer of amyloid- $\beta_{1}-42$," Journal of Neuroscience, vol. 25, no. 3, pp. 672-679, 2005.

[43] R. Selvatici, L. Marani, S. Marino, and A. Siniscalchi, "In vitro mitochondrial failure and oxidative stress mimic biochemical features of Alzheimer disease," Neurochemistry International, vol. 63, no. 2, pp. 112-120, 2013.

[44] J. Y. Lee, Y. Park, S. Pun, S. S. Lee, J. F. Lo, and L. P. Lee, "Real-time investigation of cytochrome c release profiles in living neuronal cells undergoing amyloid beta oligomerinduced apoptosis," Nanoscale, vol. 7, no. 23, pp. 10340-10343, 2015.

[45] N. Lin, L. Xiong, R. Zhang et al., "Erratum to: Injection of A $\beta 1$ 40 into hippocampus induced cognitive lesion associated with 
neuronal apoptosis and multiple gene expressions in the tree shrew," Apoptosis, vol. 21, no. 5, pp. 621-640, 2016.

[46] C. Zhao, C. Lv, H. Li et al., "Geniposide protects primary cortical neurons against oligomeric A $\beta 1$-42-induced neurotoxicity through a mitochondrial pathway," PLoS ONE, vol. 11, no. 4, Article ID e0152551, 2016.

[47] I. L. Ferreira, E. Ferreiro, J. Schmidt et al., "A $\beta$ and NMDAR activation cause mitochondrial dysfunction involving ER calcium release," Neurobiology of Aging, vol. 36, no. 2, pp. 680-692, 2015.

[48] B. Antonsson, F. Conti, A. Ciavatta et al., "Inhibition of Bax channel-forming activity by Bcl-2," Science, vol. 277 , no. 5324, pp. 370-372, 1997.

[49] S. L. Schendel, M. Montal, and J. C. Reed, "Bcl-2 family proteins as ion-channels," Cell Death and Differentiation, vol. 5, no. 5, pp. 372-380, 1998.

[50] X. T. Jia, T. Ye, and L. Yuan, "Exendin-4, a glucagon-like peptide 1 receptor agonist, protects against amyloid-beta peptideinduced impairment of spatial learning and memory in rats," Physiology \& Behavior, vol. 159, pp. 72-79, 2016.

[51] N. Suganthy, D. S. Malar, and K. P. Devi, "Rhizophora mucronata attenuates beta-amyloid induced cognitive dysfunction, oxidative stress and cholinergic deficit in Alzheimer's disease animal model," Metabolic Brain Disease, vol. 31, no. 4, pp. 937-949, 2016. 


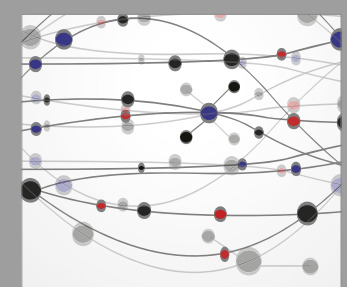

The Scientific World Journal
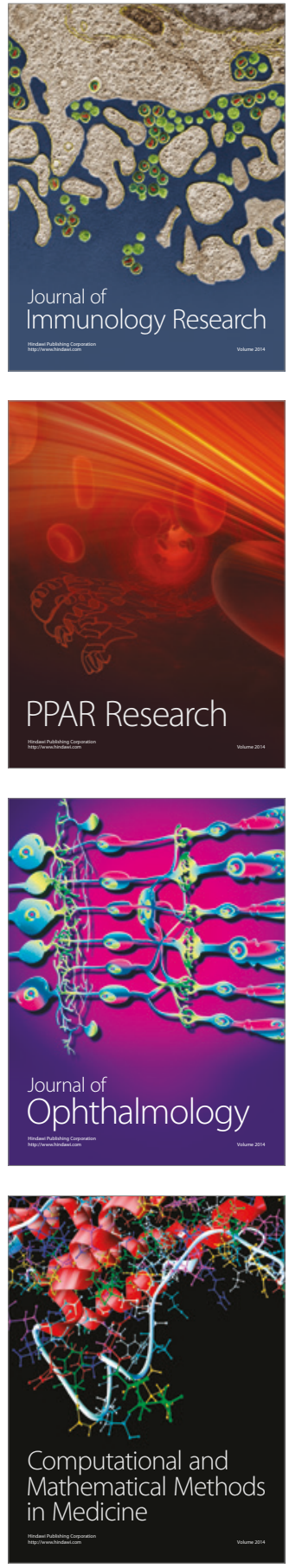

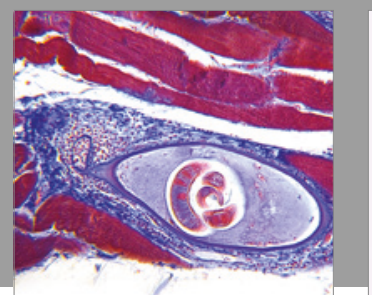

Gastroenterology Research and Practice
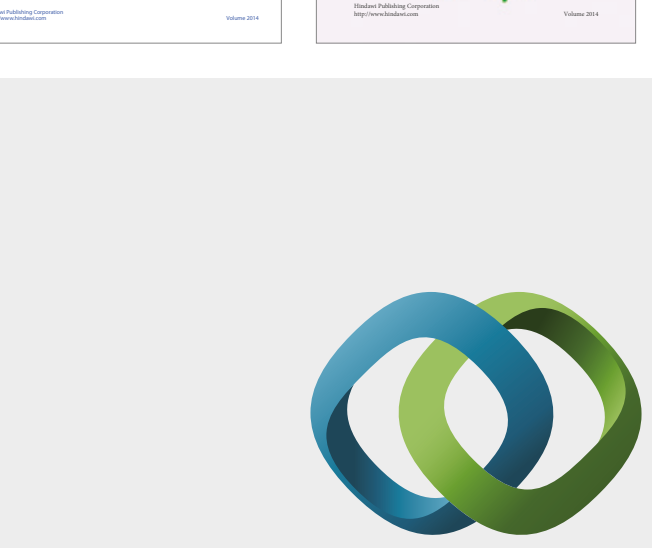

\section{Hindawi}

Submit your manuscripts at

https://www.hindawi.com
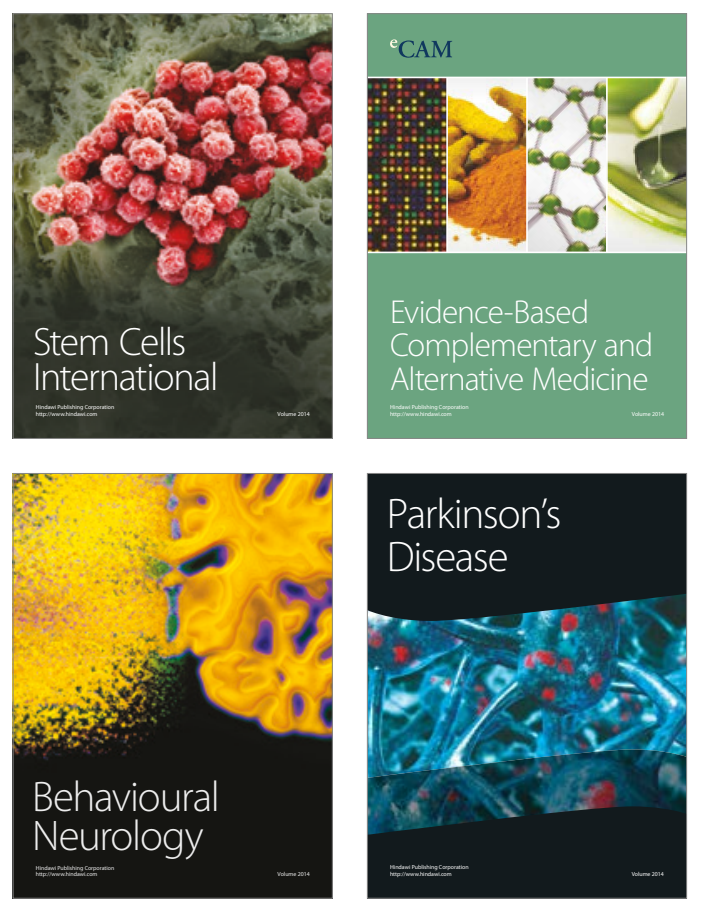
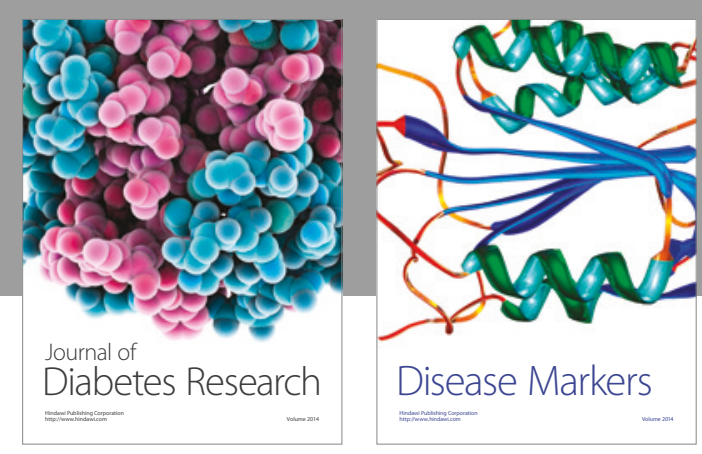

Disease Markers
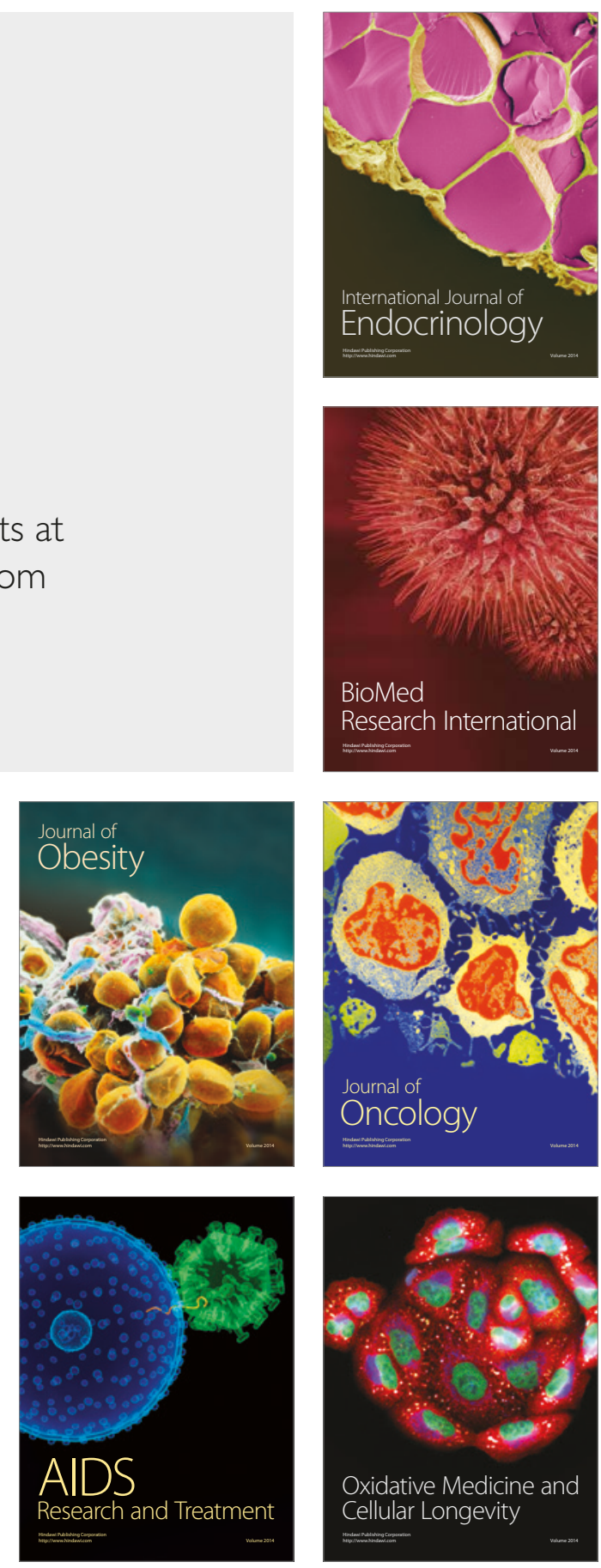